\title{
GRASSLAND FARMING AND PROGRESS ON NOKOMAI STATION
}

\author{
F. L. HoRE \\ Nevis, Cromwell
}

Nokoma S Station, of some 38500 ha, lies almost equally within Southland and Otago and is connected through the Nevis Valley.

Following 13 years as a fat lamb farmer on the low country, I moved back to the high mountain country of my childhood and took possession of Nokomai Station on July 1, 1950.

Until 1963 it was run by a manager but I felt that, contrary to other opinions, Nokomai still had enormous potential for improvement. Evidence from experimental plots, field days and discussions confirmed my opinions and so I decided to take up the challenge with a developmental programme.

A "run plan" was worked out with the Southland Catchment Board and the programme initiated. Over the next 5 years 2600 ha were over-sown and topdressed and $24 \mathrm{~km}$ of fencing erected at a total cost of round $\$ 56000$. After completion of the run plan programme, the established procedure of oversowing and topdressing, fencing and roading was continued. After a lapse of 5 years a second run plan was taken up to aid the continuing development, with greater emphasis being placed on obtaining better utilization of pasture through subdivision and a swing to more cattle and lamb production.

\section{GRASSLAND MANAGEMENT}

A large part of the Southland area and all but 1600 ha of the Otago (Nevis) country are high and only suitable for summer grazing on account of snow. Approximately 4000 ha of the lower end of the station in Southland have been topdressed and oversown by aeroplane. Initially $190 \mathrm{~kg} / \mathrm{ha}$ of double fortified molybdic superphosphate was applied with $1.4 \mathrm{~kg}$ of white clover, $1.4 \mathrm{~kg}$ Montgomery clover, $0.9 \mathrm{~kg}$ dogstail, $0.5 \mathrm{~kg}$ timothy and 2.7 to $3.2 \mathrm{~kg}$ of cocksfoot and has proved a "productive pasture mixture. Maintenance topdressing is now $125 \mathrm{~kg} / \mathrm{ha}$ sulphurized superphosphate applied annually.

Ryegrass was tried one year instead of cocksfoot without success. Similarly alsike clover was tried one year by cutting down the rest of the clover, but it did not show up. However, 
PROCEEDINGS N.Z. GRASSLAND ASSOCIATION

sowings have generally proved successful and all blocks have shown remarkable results in the first year following aerial sowing. Nokomai really likes superphosphate and seed. Shelled cocksfoot did not seem to be any better than other cocksfoot, and burning 12 months before initial topdressing proved no better than burning and aerial topdressing within a day or two. From several trials, early August was found to be the best time for sowing.

Several airstrips were also established on the station during these periods and I consider that this investment and the consequent use of the aeroplane was a major factor in the overall development of the station. It enabled a vast improvement in grassland production to be achieved and thereby provided the necessary feed for increased stock numbers and performance. With the introduction of the improved pasture species and topdressing, previous palatability problems have been overcome and much greater utilization of pasture by stock achieved. I still consider our rate of fertilizer is light $(125 \mathrm{~kg} / \mathrm{ha}$ sulphurized superphosphate annually) but it has increased pasture production and palatability greatly. The station also has its own aeroplane which in such extensive areas is invaluable for stock management.

In the early stages the blocks were left unstocked until after the first sowing. However, this allowed browntop and sweet vernal to grow long and rank and it has proved more satisfactory to keep stock on right through.

The high summer country is showing great and encouraging signs of improvement through better grazing management. The movement of stock from earlier improved low country plus the increased topdressing policy has assisted the spread of the allimportant white clover and it is now moving into gullies and swamps and showing on steep faces previously of little or no value to stock. The introduction of beehives up to $900 \mathrm{~m}$ has been important in aiding clover seed production and spread and I consider that bees have a great influence on the development of tussock lands. Previously gullies were filled with rank grass and scrub but with fertilizer and the sowing of improved grasses and clovers these gullies are now more open through cattle breaking down the scrub in search of the more palatable, more productive grassland species. Extremely heavy stands of broom, sweet brier and gorse have been initially controlled by spraying with 2,4,5-T.

All topdressed blocks have been fenced or were fenced. Because of the size of the station these blocks are generally much 
larger than recommended and might well be more productive if smaller. They range from 160 to 7.30 ha. If reduced to, say, 80 ha, however, there .would be a greater shepherding demand. The work of the station revolves around the seasons which dictate stock management.

As with all mountain country, as many stock as possible are put on the top snow country in summer and are subsequently mustered in the autumn, brought to the homestead and drafted to the winter country.

\section{STOCK MANAGEMENT}

After taking possession of Nokomai in 1950, a considerable reorganization of sheep and policy was undertaken. Severe culling on teeth wear and wool quality was adopted and all Romney rams replaced with halfbied rams. Sheep numbers then stood at 17 OOO-odd halfbred sheep and have increased over the last ten years to 34000 of which 14000 ewes achieve 94\% lambing. All two-tooth ewes go to the ram. Cattle numbers over a similar period have increased from 30 to 1500 Herefords wintered. Hacks are used whenever possible and are all bred and broken on the station.

The fall muster starts on or about April 4 and takes only 13 days with good weather. The Nevis mob (8-10 000 approximately) is drafted at the out-station yards where the stragglers are taken off, also 1500 to 2000 clear-faced wethers are left to winter down on the lower altitude country of the Nevis. All remaining sheep (approximately 24 000) on the summer country are then taken down to the homestead and redrafted on to safer winter country.

Contract crutching of the wethers starts soon after the commencement of 'drafting. The wethers are counted and then put on different blocks for the winter. The two-tooths go on the "warmest" country. The two-tooth ewes are also crutched and put on a block for tupping, while the older ewes, having been crutched at weaning, go on their separate topdressed blocks for tupping. Rams go out on April 29 at 25 to 1000 for approximately 6 weeks.

Just before pre-lamb shearing hoggets are mustered and drenched with thiabendazole and selenium and put on turnips or swedes and. hay either grown on the property or purchased from nearby Swede-producing areas. A month or 5 weeks' supply is enough. Following the pre-lamb shearing, ewes are put on blocks 
to lamb quietly by themselves and the shepherds then take lambing jobs down country. As the lambs are docked at 3 to 4 weeks of age, suitable mobs are allowed to drift into paddocks and then put out for final mustering and cleaning up.

Hogget shearing commences on approximately October 7 followed by the wethers. The hoggets are put back on topdressed blocks then on to higher country in December and finally to summer country in early February. In contrast, wethers are let go with all gates open to the Nevis and it takes only about 7 to 10 days for the first to reach the back boundary $40 \mathrm{~km}$ away.

Weaning is done at the end of January when lambs are sorted and 6000-odd suitable lambs are kept. The rest are drafted and usually 1500 to 1900 are put into the works. All the ewes and lambs are then eye-clipped, crutched, dipped and lambs drenched. The lambs to be kept for the flock are put on topdressed blocks and the sale lambs spread about for fattening. Ewes are put to the summer country.

In recent years, cattle work has become a major job on the station but with experienced staff available it has dovetailed very well with the sheep work. For example, the bulls are put out on November 14 and the calves are marked in early December. Cows and heifers are hunted together for the bulls at every opportunity on the topdressed country.

In early March, calves are weaned, drenched, dipped and inoculated and after a good handling they are put on topdressed blocks.

Heifers are kept on topdressed blocks right through and calve as 2-year-olds. A sale of yearlings is held each year on the first Thursday in August in the station yards. The cows are brought into topdressed blocks for calving and the calves marked in early December.

To cope with the stock work the station has six sets of sheep yards and two sets of cattle yards strategically placed.

\section{STOCK HEALTH}

Ill-thrift and scours were a menace years ago but thanks to modern drenches they are gone. There is a set system of drenching - of lambs at weaning, at the end of April, in August and in September. All ewes are drenched when pre-lamb shorn. Calves are drenched at weaning and sometimes in early winter. All drenches contain selenium.

The station is subject to snow, at times heavy, and this can be a major problem. For example, during the severe falls of 
June/ July 1948, 1969 and 1972, it was necessary to call in the services of a helicopter to put shepherds out on the top side of stranded sheep. Flooding of the rivers and creeks is another hazard which can cause inwnvenience and danger.

In 1950, I had two very young sons and, in purchasing Nokomai, staked my future life on their being tussock grassland men. Fortunately this has proved right. I firmly believe that the future of the tussock grasslands depends very much on the initiative of the young men and women who are prepared to take the ups and downs of this way of life, which is undoubtedly the healthiest and most invigorating possible — and the ups far outweigh the downs. 